\title{
Analysis of the Perceptions of Administrators on the Educations Regulations
}

\author{
Saduman Kapusuzoglu, Zubeyde Copur \\ Hacettepe University, Beytepe-Ankara, Turkey \\ saduman.kapusuzoglu@hacettepe.edu.tr
}

\begin{abstract}
The main purpose of the Ministry of National Education Guidance and Inspection Directorate and Education Inspectors Directorates Regulation consists of defining the organizations and duties of these directorates. In this respect, the regulation deals with the power and responsibilities of education inspectors to be appointed in the directorates separately and regulates issues such as their appointment, employment, training and replacement; in short all working style and principles. In this study, it is aimed at analyzing and evaluating the Ministry of National Education Guidance and Supervision Directorate and Education Inspectors Directorates Regulation taking the views of inspectors in the dimensions of structure, process and understanding. In line with this purpose, the views of education inspectors $(\mathrm{N}=86)$ have been obtained by Baskan and Kapusuzoğlu (2013) through a survey of 25 items developed in line with the regulations. The obtained data has been analyzed through averages, the T- test, Anova and Tukey-B tests. As a result of the study, it has been concluded that the inspectors do not find the application terms related to the competition examination and the changes made in terms of the examination board, regulations made in terms of the reclamation period and the oral examination process "appropriate" and that they find the regulations related to the written examination subjects and score weight, their training and appointment "partially appropriate." In addition, the views of the inspectors do not display differences based on personal characteristics with the exception of terms of service.
\end{abstract}

\section{Keywords: Education inspector, guidance and inspection directorate, regulation}

\section{Introduction}

Organizational purposes which we define as the founding reason of organizations determine the actions of individuals which constitute organizations (Terzi, 1996). Whether an organization operates in line with its purposes is determined through the inspection mechanism (Uslu, 2013). The concept of inspection is defined in the Economic Terms Dictionary as "a period of collecting evidence and evaluation by an expert unit with the purpose of determining the suitability of information related to a state or private organization to predetermined scales and reporting". It is defined in the Educational Terms Dictionary as "The analysis, examination and investigation of education and teaching activities to determine whether these are carried out in accordance with the effective laws, regulations, statutes and general instructions (TLS). According to Başaran (2000), inspection is the process of monitoring an organization to prevent it from deviating from the aims it has planned and if necessary, correcting its activities. Although the concepts of inspection and supervision are used interchangeably in our country, the words inspection, inspector, auditor are used in legal texts and job descriptions rather than supervision (Ergün et al., 2014). In foreign sources, "inspection" is used for surveillance based on control, whereas "supervision" is used for more detailed inspection (Başaran, 2000:8). When considered as a sub-system of education management, inspection expresses the development of education and increasing the Professional development of teachers (Blumberg, 1980). According to Taymaz (1997), inspection is the process of controlling human behaviors for the benefit of the public and organizations in order to determine whether institutions are able to realize their predetermined aims. It can be stated that inspection has two basic aims: while the first of these is to preserve the balance of organizations, the second is to show faults to correct them and prevent the repetition of these faults (Tortop et al., 2007).

Legal Basis of Education Inspection: As the legal basis of education inspection, Republic of Turkey's Constitution - Article 42, the Law on Unification of Education - Article 1, National Education Basic Law no: 1739 - Article 17, Article 56 and Article 58, Law on Organization and Duties of Ministry of National Education no: 3797 - Article 2 and Article 27, Law on Private Education Institutions no: 625 - Article 2, Article 44, 
Article 45 and Article 46, Law on Primary and Secondary Education Teachers' Promotion and Penalties no: 1702 - Article 4, Vocational Education Law no: 3308 and Legislative Decree no: 652 can be listed. The issue of inspection is given place to in these legal bases as follows:

- Republic of Turkey's Constitution - Article 42: No one can be deprived of the right of education and training. The scope of the right of education is determined and regulated by law. Education and training is carried out in line with Atatürk's principles and reforms on the basis of the principles of contemporary science and education under the observance and supervision of the state.

- The Law on Unification of Education - Article 1: All scientific and educational institutions in Turkey are under the Ministry of National Education.

- National Education Basic Law no: 1739 - Article 17: The aims of National Education are not only attempted to be realized in official and private educational institutions, but at homes, offices as well everywhere and at every opportunity. Educational activities of all official, private and voluntary institution are subject to the inspection of the Ministry of National Education in terms of the aims of National Education. Article 56: The Ministry of National Education is responsible for carrying out, observing and inspecting the education and training service in accordance with the provisions of this law on behalf of the state. Article 58: (Amendment: 16/6/1983-2842/16 Article): primary schools, highschools or their equivalents in Turkey cannot be opened without the permission of the Ministry of National Education. The degree of schools opened or to be opened by the Ministry of National Education or another ministry (including military high-schools) and private schools belong to the Ministry of National Education.

- Law on Organization and Duties of Ministry of National Education no: 3797 - Article 2: The duties of the Ministry of National Education are as follows: to plan, program, implement, monitor and control education and training services targeted at teachers and students in the educational institutions at all levels affiliated to the Ministry with the objective of raising individuals who are committed to Atatürk's principles and reforms, and to the Atatürk's nationalism defined in the Constitution of the Republic of Turkey, who adopt, protect and develop the national, ethical, spiritual, historical and cultural values of the Turkish nation, who love and elevate their families, homeland and nation, who are aware of their duties and responsibilities to the Republic of Turkey - which is a democratic, secular and social state ruled by law based on human rights and the basic principles defined at the beginning of the Constitution - and who behave accordingly; Article 27: states the duties of the Inspection Board Directorate's on behalf of the Minister upon the instruction or approval of the Minister.

- Law on Primary and Secondary Education Teachers' Promotion and Penalties no: 1702 - Article 4: The first appointment is carried out as an intern. At the end of the internship year, those interns whose capability and teaching skills are determined through the teaching records and inspection report receive the title of teachers.

- Vocational Education Law no: 3308 - Article 41: According to the provisions of this law, The training of candidates, apprentices and foremen given by public and private organizations and institutions other than the educational institutions affiliated with the Ministry and vocational training given by organizations are inspected by the Ministry and Ministry of Labor and Social Security.

- Legislative Decree no: 652: With this decree, the Guidance and Inspection Directorate has been founded and inspection's preventing irregularities, educational and guiding approach has been underlined. Two separate inspection units have been founded: one being the Guidance and Inspection Directorate und er the body of the Ministry, the other being Education Inspectors Directorate under the Provincial Directorate for National Education. With this Legislative Decree, the inspectors under the ministry have been called auditors and the inspectors under the national education directorate have been called supervisors.

The Ministry of National Education Guidance and Inspection Directorate and Education Inspectors Directorates Regulation which is the subject of this study embody the latest regulations in education inspection. When the literature was reviewed, a scientific study related to this regulation has not been found. Therefore, it has been decided to analyze in particular the regulations related to the competition and competency exams of deputy inspectors, the issue of their appointment and replacement, authority and responsibilities in detail in this study. 
The Ministry of National Education Guidance and Inspection Directorate and Education Inspectors

Directorates Regulation: The aim of this regulation can be summarized under four items:

- To regulate the organization and duties of The Ministry of National Education Guidance and Inspection Directorate and Education Inspectors Directorates,

- To regulate the duties, authority and responsibilities of Guidance and Inspection Head and education inspectors and deputy education inspectors to be appointed at the Guidance and Inspection Directorate, their appointment, employment and working methods and principles,

- To regulate the qualifications, competition and competency exams, placement, appointment, replacement, authorities and responsibilities of duty of education inspectors and deputy education inspectors,

- To regulate the working methods and principles of personnel employed at the Guidance and Inspection Directorate and education inspectors directorate office.

If we touch upon the striking aspects of the Ministry of National Education Guidance and Inspection Directorate and Education Inspectors Directorates Regulation separately, firstly an amendment has been done in the competition examination commission and with the new regulation, it has been considered appropriate for the Examination Commission to consist of a Guidance and Inspection Head and three general directors or department heads with the suggestion of the Undersecretary and approval of the Minister under the chairmanship of the Undersecretary or Deputy Undersecretary. The teacher field information under the written examination subjects has been completely removed. The age limit, which is one of the terms of applying for the deputy inspector competition examination has been reduced from "age 40 to age 25". The term of having received the minimum score based on the score type indicated in the Public Personnel Selection Examination competition examination announcement for people who have not completed 8 years of service in teaching to the application terms for the deputy inspector exam. The oral examination questions are prepared by the Competition and Competence Examination Committee. In the oral examination, the candidates select the questions they are supposed to answer by drawing lots. The item of the period for each candidate from the beginning of the oral examination until its end is vocally and visually recorded has been removed. The reclamation period for the results of the written and oral examination has been reduced to 5 days from 10 days.

The Purpose of the Study: The purpose of this study is to analyze and evaluate the Ministry of National Education Guidance and Supervision Directorate and Education Inspectors Directorates Regulation based on the views of inspectors in the dimensions of structure, process and understanding. In this respect, the answers to the following questions have been sought for:

- What are the views and suggestions of Education Inspectors in relation to the regulations made in terms of their appointment, training and replacement dimensions in the Regulation in question?

- Do the views of Education Inspectors differ in accordance with personal characteristics (branch, educational status and service duration)?

\section{Methodology}

Research Model: The study is a descriptive survey type study.

Study Group: The study's study group consists of auditors employed at the National Education Directors of selected cities $(\mathrm{N}=86)$.

Data Collection Tool: With the purpose of determining the views of Education Inspectors, the survey developed by Baskan and Kapusuzoğlu (2013) has been taken as the basis and a survey based on the regulation consisting of three parts has been developed and used by the researchers. The first part of the survey consists of personal information (4 items), the second part consists of 25 items related to different dimensions which have been amended with the new regulation (competition examination, examination application terms, examination subjects and score weights, success criteria, the appointment, training and employment of deputy inspectors, regional service term, the identification of the need for inspectors, replacements (related to health and spouses, education excuse), the points to be complied by the inspectors, 
the expansion of the scope of duties, administrative duties and procedures, temporary employment) and the third part consists of an open-ended question which aims at determining the views and suggestions of Education Inspectors in relation to the new regulation.

Analysis of Data: In the study, data obtained through the survey have been coded and analyzed with the SPSS 22.0 package program. In the study, averages, T-Test, Anova and Tukey-B test have been applied in the analysis of the sub-problems. In the interpretation of the obtained data, the score intervals indicated in Table 1 below have been taken as the basis:

Table 1: Score Limits Related to the Options

\begin{tabular}{lll}
\hline Options & Score Given & Score Intervals \\
\hline I Totally Disagree & 1 & $1.00-1.79$ \\
I Disagree & 2 & $1.80-2.59$ \\
I Partially Approve & 3 & $2.60-3.39$ \\
I Approve to a Large & 4 & $3.40-4.19$ \\
Extent & 5 & $4.20-5.00$ \\
$\quad$ I Totally Approve & 5
\end{tabular}

Analysis of Data: The reliability coefficient of the survey is Cronbach Alfa $=0.877$.

\section{Findings and Discussion}

Findings Related to the Personal Characteristics of Education Inspectors: The personal characteristics of the inspectors have been presented in Table 2 . When Table 2 is analyzed, it can be seen that $64 \%$ of the inspectors are class teachers and 36\% are culture lesson teachers. $37 \%$ of the inspectors have completed Education Administration and Inspection undergraduate education, 40\% have completed undergraduate education and $23 \%$ have completed post-graduate education. $7 \%$ of the inspectors have completed 10-15 years, $9 \%$ have completed $16-20$ years and $56 \%$ have completed $26-30$ years of service.

Table 2: Personal Characteristics of Education Inspectors

\begin{tabular}{llll}
\hline \multicolumn{1}{c}{ Personal Information } & $\begin{array}{l}\text { Inspectors } \\
\text { f }\end{array}$ & $\mathbf{\%}$ \\
\hline \multirow{5}{*}{ Branch } & Class Teachers & 55 & 63,95 \\
& Culture Lesson & & \\
& Teachers & 31 & 36,05 \\
& Total & 86 & 100,00 \\
& Undergraduate & 32 & 37,21 \\
& Education & & \\
Educational Status & Completion & & 39,53 \\
& Undergraduate & 34 & 23,26 \\
& Post-graduate & 20 & 100,00 \\
& Total & 86 & 6,98 \\
& 10-15 years & 6 & 9,30 \\
Duration of Service & $16-20$ years & 8 & 27,91 \\
& 21-25 years & 24 & 55,81 \\
& 26-30+years & 48 & 100 \\
\hline
\end{tabular}

Findings Related to the First Sub-Problem: The inspectors' views on the changes made with the new regulation in the indicated dimensions have been presented in Table 3. 
Table 3: Views of the Inspectors

Views
1) It is suitable that the Examination Commission consists of a Guidance and
Inspection Head and three general directors or department heads with the
suggestion of the Undersecretary and approval of the Minister under the
chairmanship of the Undersecretary or Deputy Undersecretary.
2) It is appropriate to remove the explanation "The Competition and Competency
Examination Commission consisting of the Head of the Inspection Board or a
deputy head appointed by the Head of the Inspection Board, Primary Education
General Director or a deputy general director appointed by the Primary
Education General Director, Personnel General Director or a deputy general
director appointed by the Personnel General Director and a head of education
inspectors of a city determined by the Undersecretary under the chairmanship of
the Undersecretary or a deputy undersecretary appointed by the Undersecretary
to be formed."

3) In relation to the written examination subjects, it is appropriate to add the Public Procurement Law no: 4734 in addition to the Constitution of the Republic of Turkey; General Principles, Fundamental Rights and Duties, Principle organizations of the State and laws no: 4982, 3071, 5542, 4483, 5018, 657 and 3628 which were in the old regulation to the subjects of the examination.

4) In relation to the written examination subjects It is appropriate to completely remove "Teaching Occupational Knowledge" from the subjects of the examination.

5) In relation to the score weights of the written examination subjects, it is appropriate to increase the weight of the laws from $15 \%$ to $20 \%$, totally remove teaching occupational knowledge, and increase special field knowledge from $25 \%$ to $40 \%$ and increase national education regulation from $15 \%$ to $20 \%$.

6) In relation to the oral examination, it is appropriate to totally remove the explanation " $50 \%$ of the subjects of the oral examination for deputy inspectors and score weights consist of written examination subjects indicated in the first paragraph; $30 \%$ consists of narration and interpretation skill, $10 \%$ consists of representation skill and 10\% consists of attitude and behavior."

7) It is appropriate to reduce the age limit, which is one of the application terms of the deputy inspector competition examination, from 40 to 35 .

8) It is appropriate to change the article "To be a graduate of an at least 4 years higher-education" which is one of the terms of the deputy inspector examination to "To be a graduate of faculties of education, science and literature, economics and administrative sciences, economics, business administration, theology or higher education institutions in the country or abroad whose equivalence is approved by the Higher Education Board."

9) It is appropriate to remove the expression "Not having taken the competition examination more than twice" which is one of the terms of application for the deputy inspector examination.

10) It is appropriate to add the article "having received the minimum score based on the score type indicated in the competition examinations' announcements in the Public Personnel Selection Examination for people who 


Views
have not completed 8 years in teaching" to the deputy inspector examination's
application terms.

11) In relation to the grading of the written examination, the arrangement "The written examination is graded over 100 full points. The written examination results are listed separately in terms of areas. Beginning with the candidates who receive the highest scores in the written examination in terms of their areas, candidates 4 times the number of announced positions are entitled to enter the oral examination. The candidates who receive the same score as the last candidate are also invited to the oral examination" is appropriate.

12) It is appropriate to remove the article "The Competition and Competency Commission gets the oral examination questions prepared. In the oral examination, the candidates choose the questions they are supposed to answer by drawing lots. The period for each candidate from the beginning of the oral examination until its end is vocally and visually recorded."

13) It is appropriate to remove the article "In case the scores are equal to each other in the competition examination results; successively the following candidates are given priority: those who have completed their doctorates in educational administration, inspection, planning and economy, candidates who have completed their doctorates in their own fields, candidates who have completed post-graduate education in educational administration, inspection, planning and economy, candidates who have completed their post-graduate education in their own fields, candidates employed in institution directorates, in foreign institutions and candidates who have more service years."

14) It is appropriate to add the article "In case candidates in the end of the final candidate list have equal scores, successively candidate with the highest written examination score, oral examination score, PPSE score and diploma score is given place to in the final candidate list. In case the scores of candidates to be appointed as deputy inspectors are equal to each other, then the candidate to be appointed is determined in the same manner" to the new regulation.

15) It is appropriate to reduce the announcement date of the written examination results from the latest 15 days to the latest 10 days from the date of the examination and to increase the announcement date of the oral examination results from the latest 5 days to the latest 10 days.

16) It is appropriate to reduce the reclamation period for the written and oral examination results from 10 days to 5 days.

17) It is appropriate to reduce regional service duration from 5 years to 4 years in the third service regions.

18) It is appropriate to amend the article "The inspector needs of cities are determined each year by the appointment of an inspector for 250 personnel through official approval prior to the appointment and replacement period" to "The inspector needs of cities are determined by taking the number of personnel and institution numbers in the cities and jointly by the Directorate and Human Resources General Directorate." 


\begin{tabular}{l} 
Views \\
\hline is appropriate: "In cases where a person is determined as having a spouse, \\
children and sibling who is disabled to the degree of not being able to continue \\
his life without the help or care of others with the report of the health \\
commission and documented by the special education evaluation board as having \\
to receive education and training at official or special education and training \\
institutions located at places other than the civil service location, then the \\
inspectors are appointed to one of the cities where there are special and training \\
institutions and there is a vacant position upon their request."
\end{tabular}

20) It is appropriate to completely remove displacements due to the excuse of education from the regulation.

21) In relation to the duties of Education Inspectors Directorate, it is appropriate to remove the article "Institutions establishing inspection areas and inspection groups by taking criteria such as the geographical location, transportation conditions, physical proximity, characteristics, number of administrators, teachers and other personnel into consideration and carrying into effect with the approval of the governor."

22) In relation to the appointment of the Head of Education Inspectors, it is appropriate to amend the article "Three candidates are determined for the Head of Education Inspectors position by the governorships among candidates who have served as inspectors at least for 10 years and these candidates are suggested to the Personnel General Directorate. In case three candidates with the qualification of having served as inspectors for at least 10 years cannot be found to be appointed as the Head, then candidates meeting the other criteria are suggested to the Personnel General Directorate by the governorships. The Personnel General Directorate appoints one of the candidates as Head for three years with the approval of the undersecretary by taking educational status and seniority into consideration" to "The Head of Education Inspectors is chosen among the inspectors and appointed for 4 years with the suggestion of the Head, assent of the Undersecretary and approval of the Minister."

23) In relation to the appointment of the Deputy Head of Education Inspectors, the arrangement "The number of inspectors and deputy inspectors are determined as one in cities in which there are 30 or less inspectors, as two in cities in which there are 31-100 inspectors, as three in cities in which there are 101-200 inspectors, as four in cities in which there are 201-300 inspectors and as five in cities in which there are more than 301 inspectors and are chosen from the inspectors employed in that city with the suggestion of the Head of Education Inspectors, proposal of the Provincial Director of National Education and the approval of the Governor and appointed as Deputy Head of Education Inspectors for 2 years."

24) In relation to the duties and authority of inspectors and deputy inspectors, it is appropriate to add the article "The leaves of officials of institution and organizations which are being inspected can be postponed until the completion of the inspection in case the inspector find it necessary, with the exception of using leaves which have been given prior to the inspection and illnesses and similar compulsory reasons."

25) In relation to the duties and authority of inspectors and deputy inspectors, it is appropriate to add the article "As long as the inspection continues, the officials of the institution cannot be given leaves outside of the knowledge of the inspector."

Total 
According to data obtained from Table 3, the views of inspectors can be summarized as follows:

- The inspectors "totally disapprove" the reduction of the reclamation period for the written and oral examinations from 10 days to 5 days.

- The inspectors "disapprove" the amendment made in relation to the examination commission and the reduction of age limit which is one of the application terms for the examination from 40 to 35; the amendment in the new regulation that oral examinations will not be recorded, giving priority to those candidates with the highest PPSE score and diploma score in case of equal examination scores with the new regulation while the priority was given to candidates with post-graduate degrees in the old regulation.

- The inspectors "partially approve" all amendments related to examination subjects and their weights.

- The inspectors approve to a large extent that the limitation of not having taken the competition exam more than twice which is one of the application terms, bringing PPSE obligation to the application terms and the expansion of the health condition excuse and the inclusion of siblings besides spouses and children within the scope as well.

The open-ended question which is the 26th item of the survey given to the inspectors "What are the additions, elimination, amendments you would like to be made in the regulation?" has been answered by only 8 of the 86 inspectors. The answers are as follows:

- "I do not believe that Guidance and Inspection Directorate having separate regulations for the Directorate and Education Inspectors is appropriate.

- "Additionally, I think that the law should not be amended against the Constitution and the regulation against the law."

- "The inspectors should no longer be affiliated to the Provincial Directorate for National Education in line with the EU norms."

- "The Ministry's uniting with the Inspectors has been a good development. The same work was being done. However, they receive 1700 TL more in their employee personal rights.

- "I think that inspectorships should have a school again. 'Educational Administration, Inspection, Planning and Economy' departments should be opened."

- "This structure should firstly be removed from the body of the Provincial Directorates for National Education. The PDNEwork 1000\% politically. Therefore, conflicts are experienced with the inspectors. The mood of the institution gets wrecked".

- "As it has been indicated in the EU education report, in line with the view that 'inspectors who inspect the implementations of the Provincial National Education Directors being affiliated with Provincial National Education Directorates is against the spirit of inspection", inspectors' affiliation with them should be ended."

- "The privileges between the financial rights and personal rights of inspectors should be removed and the level of both should be raised to the level of rights in the other ministries."

Findings Related to the Second Sub-Problem: The findings related to the problem "Do the views of education inspectors display differences in accordance with personal characteristics?" have been presented below under sub-headings.

In terms of Branches:

Table 4: The T-test in relation to the comparison in accordance with the branches

\begin{tabular}{llllllll}
\hline $\begin{array}{c}\text { General } \\
\text { Average }\end{array}$ & Branch & $\mathbf{N}$ & $\bar{x}$ & SS & sd & t & P \\
\hline & $\begin{array}{l}\text { Class } \\
\text { teacher }\end{array}$ & 55 & 3,14 & 0,47 & & & \\
$\begin{array}{l}\text { Culture } \\
\text { Lesson } \\
\text { Teacher }\end{array}$ & 31 & 2,97 & 0,68 & 72 & 1,226 & 0,224 \\
\hline
\end{tabular}

${ }^{*} \mathrm{p}>0,05$ 
When Table 4 is analyzed, it can be stated that there is statistically no significant difference between the views of inspectors as a result of the T-test carried out in relation to the comparison made between the branches ( $p>0.05)$.

\section{In terms of Education:}

Table 5: Variance Analysis in Relation to the Comparison of Educational State Variable

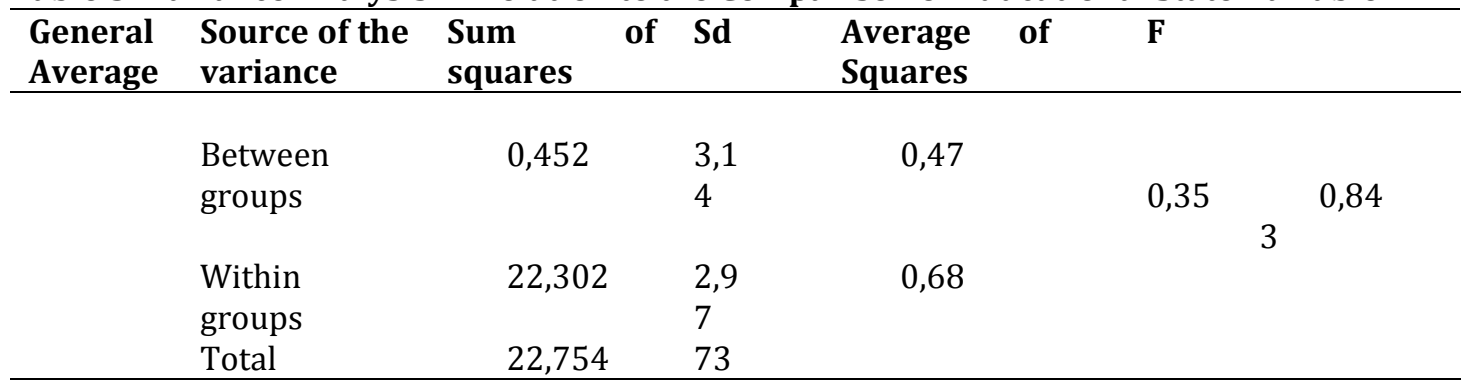

1) Graduate education completion 2) Graduate 3)Post-graduate

When the variance analysis results presented in Table 5 on the comparison of the various dimensions of the regulation and the educational status variable were analyzed, a significant difference has not been observed $(\mathrm{p}>0.05)$.

In terms of service duration: When Table 8, which is related to the comparison between the different dimensions of the regulation and the service duration of the inspectors, was analyzed, a statistically significant differences has been observed $(\mathrm{F}=13.951, \mathrm{p}<0,05)$. It has been attempted to find the source of this significant difference. With the purpose of determining between which seniority years this statistical difference took place, the Tukey-B test has been done. It has been seen that the difference has taken place between 10-15 years and 16-20 years and between 21-25 years and 26-30 years. It can be stated that there is a differences between the views of inspectors who have just begun their jobs and inspectors with seniority.

Table 6: Variance Analysis in Relation to the Comparison in accordance with the Service Duration

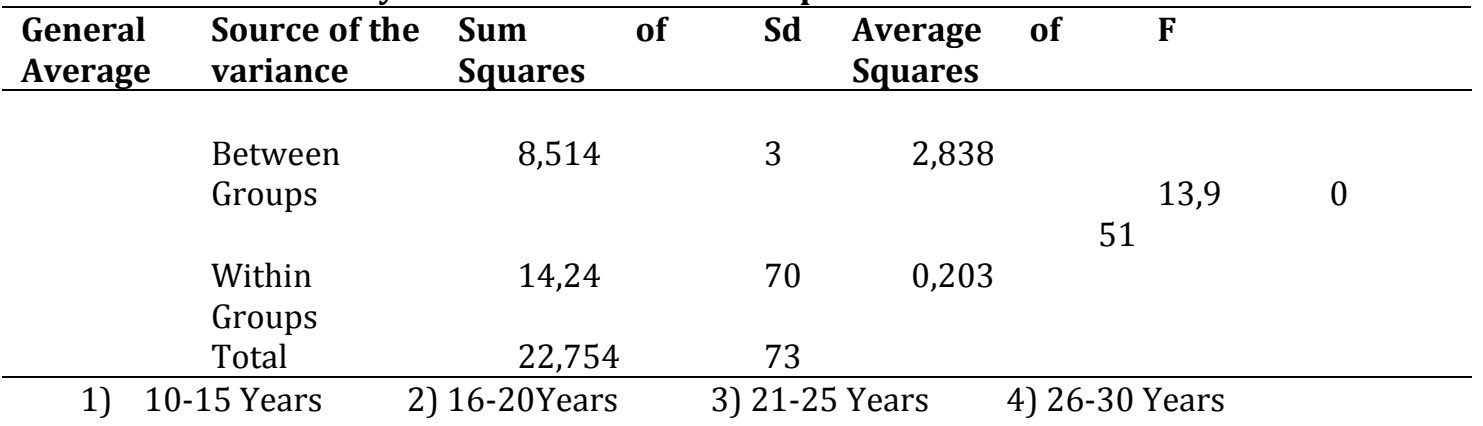

\section{Conclusion and Suggestions}

When the views of the inspectors have been evaluated in general, it has been seen that with their views supporting that there should not be a department head in examination commissions, disapproving the removal of the condition of recording the oral examination and even supporting the complete removal of the oral examination reflects the inspectors' sensitivity in terms of the examinations to be objective in practice. The inspectors' criticizing the article about the removal of giving priority to candidates with post-graduate and doctorate degrees in cases of equal scores, not approving the removal of the educational excuse from the regulation and in addition, arguing that inspectorships should have a school again shows that they respect doing scientific studies. The inspectors' are troubled about inspectors' are directly affiliated with the National Education Directorates can be interpreted as an indication that they are in command of the European Union Education Report. In addition, it can be interpreted as an indication of their efforts to keep inspection away from politics. 
The inspectors' criticizing the reduction of the reclamation period for the written and oral examination results from 10 to 5 days and arguing for the increase of this period to 15 days and in particular stating that people in the rural areas will not be able to be fully prepared during the reclamation stage can be interpreted as the indication of the need for new legal arrangements. The inspectors' openly stating the view that the privileges about their financial and personal rights should be removed can be interpreted as the indication of the need for new legal arrangements. All of the inspectors making up the study group of the study openly stating their views and suggestions are considered to have great importance in terms of contributing to other legal arrangements to be realized in the inspections system to be scientific and applicable.

\section{References}

Baskan, G. A. \& Kapusuzoglu, S. (2013). Comparative Assessment of Supervisory Regulations Related to Appointment, Training and Change of Location. Journal of Economics and Behavioral Studies, 5(3), 185-191.

Başar, H. (1998). Eğitim Denetçisi. Ankara: Pegem Publishing.

Başaran, I. E. (2000). Eğitim Yönetimi Nitelikli Okul. Ankara: Feryal Publishing.

Blumberg, A. (1980). Supervisors \& Teachers: A Private Cold War. California: McCutchan Publishing Corporation.

Ergün, M., Recepoğlu, E., Küçük, Z. A. \& Oğuz, K. (2014). Türkiye'deki Üniversitelerde Eğitim Denetimi Alanında Yapılan Lisansüstü Tezlerin Çeşitli Değișkenlere Göre İncelemesi. Kastamonu Education Journal, 22(1), 25-40.

Taymaz, H. (1997). Eğitim Sisteminde Teftiş Kavramlar İlkeler yöntemler. Ankara: TAVAK.

TDK (Türk Dil Kurumu). Ĕgitim Terimleri Sözlüğü, İktisat Terimleri Sözlüğü. <http://www.tdk.gov.tr/index.php?option=com_bts\&arama=kelime\&guid=TDK. GTS.5193875c91e145.30872510> (23/12/2012).

Terzi, A. R. (1996). İlköğretim Müfettişlerinin Teftiş Sorunları (Unpublished Thesis). Gazi University Institute of Educational Sciences, Ankara.

Tortop, N., İşbir, E., Aykaç, B., Yayman, H. \& Özer, M.A. (2007). Yönetim Bilimi. Ankara: Nobel Publishing.

Uslu, B. (2013). Eğitim Denetmenlerinin Seçimi, Atamaları ve Mali Hakları İle Yetiştirilmelerine İlişkin Sorunların İncelenmesi. Celal Bayar University Journal of Social Sciences, (11-2), 191-205. 